\title{
A QUESTÃO AMBIENTAL E A NECESSIDADE DE COOPERAÇÃO SOCIAL NA SUPERAÇÃO DOAUTOINTERESSE DE CURTO PRAZO
}

\author{
Júlio Cesar Zorzenon Costa \\ Professor associado da Universidade Federal de São Paulo (Unifesp) \\ jczorzenon@uol.com.br \\ FlávioTayra \\ Professor adjunto da Universidade Federal de São Paulo (Unifesp) \\ ftayra@unifesp.br
}

\begin{abstract}
Resumo - Sob a ditadura neoliberal do mercado globalizado, muitas das nações desenvolvidas, imersas na busca de curto prazo por competitividade econômica, acabam por não investir na adoção das políticas de sustentabilidade. Essa atitude traz consigo, de forma implícita, a suposição de que se outras nações adotarem tais políticas, elas poderão desfrutar das benesses de um modo de vida menos poluente, sem precisar assumir os custos que diminuiriam a sua competividade e sem ferir seus interesses de curto prazo. Esse comportamento entre países é seguido pelas corporações econômicas e também pelos indivíduos. Enquanto isso, a cooperação entre as partes passa ao largo. Nesse sentido, o objetivo fundamental deste artigo é responder à pergunta: qual o potencial de expansão da cooperação entre as pessoas e os povos na atual conjuntura capitalista? Adicionalmente, quais seriam os mecanismos para os indivíduos voltarem a se organizar e superar a passividade e a despolitização que os permeiam na atualidade? Reforçamos no trabalho a ideia de bens comuns e a necessidade de se reestabelecer a confiança necessária para a cooperação neste nível.
\end{abstract}

Palavras-chave: Autointeresse; Cooperação Social; Bens Comuns.

\section{THE ENVIRONMENTAL ISSUE AND THE NEED FOR SOCIAL COOPERATION IN OVERCOMING SHORT-TERM SELF-INTEREST}

\begin{abstract}
Under the neoliberal dictatorship of the globalized market, many developed nations, immersed in the short-term pursuit of economic competitiveness, end up not investing in the adoption of sustainability policies. This attitude expresses the implicit assumption that if other nations adopt such policies, they will be able to enjoy the benefits of a less polluting way of life without having to bear the costs that would diminish their competitiveness. This behavior among countries is followed by economic corporations as well as individuals. Meanwhile, the cooperation between the parties passes away. In this sense, the fundamental objective of this article will be to answer the question: what is the potential for expanding cooperation between people and peoples in the current capitalist conjuncture? In addition, what are the mechanisms for individuals to get organized again and overcome the passivity and depoliticization that permeate them today? We reinforce in the work the idea of common goods and the need to reestablish the necessary confidence for the cooperation in this level.
\end{abstract}

Keywords: Self-interest; Social Cooperation; Common Goods.

\section{INTRODUÇÃOO}

Com o advento do modo capitalista de produção, com sua teorização lógica amplamente pautada no autointeresse, que em seus últimos desdobramentos trouxe consigo a disseminação de padrões de conduta e de consumo globalizados (bem como a utilização maciça dos recursos naturais), a necessidade de cooperação e ordenamento dos recursos comuns (commons) é um debate que ainda vem sendo deixado em segundo plano, tanto nas instâncias política quanto na acadêmica. 
A abordagem principal sobre o tema da cooperação por parte da ciência econômica (ou sua dificuldade), se dá a partir da Teoria dos Jogos. Nela, o tipo de resultado a ser obtido em uma negociação dependerá do tipo de jogo: se for de caráter cooperativo, espera-se que ambos os agentes deverão chegar a um acordo benéfico para ambas as partes, situação na qual ninguém se prejudicará (ou terá menores prejuízos). A colaboração, no caso, só é possível quando os indivíduos adotam uma estratégia de cooperação com o objetivo egoísta de obter um melhor resultado para si no longo prazo. Mas, a lógica limitada ao curto prazo ainda é a tônica na atualidade.

No debate atual sobre a sustentabilidade, a dificuldade de cooperação é observada na prática. No melhor resultado econômico as previsões que dão conta de uma piora gradual dos fundamentos ambientais do planeta são subestimadas e, sorrateiramente, espera-se que outros tomem atitudes sustentáveis e que os efeitos dessa prática beneficiem a todos de uma maneira ampla. Por conta disso, as negociações em torno de um acordo global para o clima nos últimos anos têm mostrado seguidos fracassos, denotando a indisposição dos agentes em negociar. Procrastinação do problema é uma estratégia deliberada para não encarar devidamente a situação e adiá-la até o limite do insustentável.Enquanto isso, a cooperação entre as partes passa ao largo. É importante frisar, como veremos, que tal comportamento não se dá apenas na esfera dos países.

Apresentado o problema, o objetivo fundamental deste artigo será responder à pergunta: qual o potencial de expansão da cooperação entre as pessoas e os povos na atual conjuntura capitalista? Adicionalmente, quais seriam os mecanismos para os indivíduos voltarem a se organizar e superar a passividade e a despolitização que os permeiamna atualidade? Como contribuição e aporte, tentaremos qualificar possíveis formas de organização coletiva que consigam simultaneamente ampliar a democracia e incentivar práticas mais solidárias e sustentáveis sob o ponto de vista ambiental.

\section{ALTRUÍSMO E COOPERAÇÃO}

Em seu desenvolvimento, a ciência econômica conseguiu lograr um importante feito ao circunscrever o princípio baseado no amorpróprio para expor a racionalidade dos agentes econômicos: entendendo o comportamento maximizador de utilidade - autointeressado - como mola propulsora do ser humano, engendrou uma forma de análise do sistema econômico que ajuda a delinear a forma de interpretação e a organização do sistema.

Tal abordagem microeconômica pautada no autointeresse pressupõe que a partir de uma melhor divisão e especialização do trabalho, com possível geração de economias de escala, se torna viável uma alocação mais eficiente dos fatores de produção, que em decorrência tende a ativar uma série de efeitos encadeados até se atingir uma maximização do processo de racionalização, que se verificará, grosso modo, numa queda de preços, frutos de aumento de 
produtividade, e que redundará, consequentemente, num aumento de bem-estar geral. Tudo movido pelo autointeresse de maximização.

Pelo lado da oferta, não se tem dúvida de que a experiência capitalista foi extremamente bem-sucedida; mas, obviamente, não sem custos. A busca incessante pela maior lucratividade fez com que a especialização trouxesse incrementos de produtividade nunca antes visto na história econômica da humanidade, mas isso resolveu apenas parte do problema. $\mathrm{O}$ aumento do bem-estar foi observado efetivamente, e não foi pouco significativo, mas numa escala muito aquém da verificada no lado produtivo.

A racionalidade observada no processo de escolha é a pedra de toque da interpretação econômica neoclássica. Isso ocorre em razão de se admitir que os agentes decisórios sejam racionais e que isso consiste em otimizar uma função utilidade, com as restrições que couberem (o que não se baseia necessariamente em evidências empíricas). Essa noção de racionalidade é inspirada por uma visão de mundo que imagina e metodologicamente dota o homem de capacidade irrestrita de avaliar e compreender o mundo que o cerca. Nesse sentido, o individualismo metodológico fartamente utilizado pela ciência econômica é a abordagem que considera o indivíduo como a unidade de análise fundamental, a partir da qual se constrói a lógica econômica do pensamento neoclássico. Há nesse caso, um reducionismo teórico que simula que o sistema social refere-se à soma dos indivíduos que o compõem. O conjunto dos indivíduos e as interações entre eles não apresentam maior interesse, não sendo, portanto, objeto de análise mais profunda. Ou seja, os resultados das escolhas racionais envolvem claramente o ponto de vista do agente individual. Todo o programa neoclássico procura construir um quadro com unidades atomísticas individuais, como a unidade central da mecânica newtoniana a sua fonte de inspiração.

Adam Smith, fundador da ciência econômica moderna no século XVIII, via em Isaac Newton o pensador que tinha realizadoas mais importantes contribuições na filosofia de sua época. Nele inspirado, buscou tratar o processo de sociabilidade a partir de um princípio análogo, por meio da lei da oferta e da demanda. Ou seja, de modo similar ao que sucedia com a lei da gravidade, o princípio da oferta e da demanda regularia as relações entre os indivíduos, o que supõe tratar a ordem social a partir de um princípio que subordina e regula as suas relações. O princípio se baseia na redução de todos os componentes (volume de trabalhadores, volume de capital e volume de terra) a massas comparáveis entre si, uma comparabilidade que se assenta na noção de uma matéria sem forma, mas que determina a relação, supostamente sujeita a leis, entre os seres humanos. Da mesma forma que a gravidade explica o movimento dos planetas, as leis da oferta e da demanda explicariam as relações entre indivíduos e a sua integração na totalidade.

A analogia com os planetas tem lá as suas consequências. Estes, como natureza inerte, são movidos pela gravidade. A formalidade da legalidade do mercado remetia, no entanto, a um 
mundo mecânico e, em consequência, inevitável. As consequências dessa ordem legal surgem não mais como consequências ético-políticas, mas como se fossem consequências naturais, a legitimação das diferenças no mundo e na economia moderna.

Essa ainda é a visão dominante na ciência econômica (no mainstream). Nos manuais de economia, a ciência é definida como a teoria da escolha sob escassez, em que a linguagem matemática é utilizada para realizar análises baseadas nas noções de equilíbrio e maximização. Estudos agregados, quando realizados, são feitos com recurso aos microfundamentos geradores dos eventos observados. O macroequilíbrio derivaria do correto funcionamento das instâncias micro.

Antes ainda de Smith, a ideia de que vícios privados como o egoísmo e a vaidade poderiam levar a benefícios públicos, sob uma visão exclusivamente antropocêntrica, também foi uma inspiradora da formulação das teses dos economistas clássicos. Segundo Bianchi,

\footnotetext{
Mandeville chega a enunciar que os benefícios públicos resultam de ações normalmente consideradas viciosas, posto que suscitadas pela luxúria, avareza, orgulho e outros traços do caráter humano. Submetidas a uma hábil administração, tais paixões podem ser domadas num quadro institucional propício ao progresso da coletividade. Hume, a seu turno, advoga a importância da luxúria como fonte de estímulo para a geração do excedente que se torna objeto do comércio humano e, assim, incrementa o estoque de felicidade nacional (Bianchi, 1988, p. 198).
}

Metodologicamente, a construção de um homem econômico racional, autointeressado, voltado para a maximização de utilidade ou do lucro, embora uma abstração, buscou preencher um conceito de generalidade; e o seu grau de realismo, constituiu-se na aproximação possível. Dessa forma, outras características humanas como as já mencionadas, foram todas centralizadas na escolha autointeressada, um fundamento do homem.

Antes de esboçar uma análise maniqueísta da teoria, existe um ponto importante a ser considerado no individualismo metodológico da economia clássica. Bianchi e Santos apontam que autointeresse e egoísmo são conceitos muito distintos no linguajar de Adam Smith, considerando o contexto em que ele escreveu. O egoísmo seria uma exacerbação do autointeresse. Nessa interpretação, é no autointeresse e não na sua exacerbação que se baseia o argumento de Smith no tocante aos benefícios públicos: Com o egoísmo, "não haveria qualquer garantia de um resultado socialmente benéfico" (Bianchi e Santos, p.9).

A definição kantiana do esclarecimento reflete de maneira adequada aquelas características que marcaram o desenvolvimento do iluminismo entre os escoceses, do qual fez parte Smith e explica o seu posicionamento metodológico. Antes de tudo, ela coloca em primeiro plano a autonomia do sujeito: o esclarecimento consiste em tomar para si mesmo o controle do próprio destino, não delegar a outrem a direção sobre o uso do entendimento ou sobre a capacidade de deliberar sobre aquilo que deve ser feito. Isso requer vencer "a preguiça e a covardia" que fazem com que boa parcela da humanidade renuncie ao esforço de pensar por si mesma e, com espírito servil, persista sob a tutela de 
outro por toda a vida. O conceito de esclarecimento assume assim a forma de um postulado moral e, nesse sentido, diz menos respeito àquilo que se pensa - isto é, ao conteúdo de nossas reflexões - e mais ao modo como empregamos a nossa razão.

Para Kant o iluminismo não seria mais um sistema filosófico entre outros, mas corresponderia a um tipo de atitude, aquela que é própria de quem ousa conhecer por si mesmo:

Esclarecimento é a saída do homem de sua menoridade, da qual ele próprio é culpado. A menoridade é a incapacidade de fazer uso de seu entendimento sem a direção de outro indivíduo. $\mathrm{O}$ homem é o próprio culpado dessa menoridade se a causa dela não se encontra na falta de entendimento, mas na falta de decisão e coragem de servir-se de si mesmo sem a direção de outrem. Sapereaude! Tem coragem de fazer uso de teu próprio entendimento, tal é o lema do esclarecimento (Kant, 1984, p. 100).

Por outro lado, o conceito proposto por Kant remete a uma dimensão social do esclarecimento: de acordo com ele, a condição para que a humanidade escape da menoridade é a liberdade de "fazer um uso público de sua razão em todas as questões", isto é, a liberdade de "qualquer homem, enquanto sábio" dirigir seus argumentos "ao grande público do mundo letrado", tornando-os conhecidos e, desse modo, passíveis de serem discutidos publicamente (Kant, 1984, p.105).

Para a teoria econômica em si, assim fundada nesta percepção de liberdade e autointeresse, a solidariedade com as gerações futuras é um problema profundo. Isto se refere à necessidade de introdução de um caráter cooperativo nas análises econômicas do meio ambiente - e na do sistema produtivo e nos hábitos das pessoas, em geral - combater o ensimesmamento, enfim; o que se contrapõe, em forte medida, ao indivíduo maximizador autointeressado, epítome do comportamento econômico idealizado pelos economistas utilitaristas. Quando o Relatório Brundtland (WECD, 1987) prega a solidariedade para com as gerações futuras, o que propõe é a necessidade de se revisar padrões de consumo e, principalmente, de adiamento de possíveis escolhas (as escolhas intertemporais). $\mathrm{O}$ individuo egoísta maximizador deve agora preocupar-se também com as futuras gerações, superando, pois, sua perspectiva individualista e imediatista.

Tradicionalmente tão distantes e perdidas no tempo, o fato é que, desde a popularização da questão ambiental e das repercussões do aquecimento global, as futuras gerações estão cada vez mais próximas. Para os mais antigos, quantas gerações seriam? Várias gerações poderiam compreender séculos... mas os alertas do IPCC (Painel Intergovernamental sobre Mudanças Climáticas na sigla em inglês) mostram que esse futuro pode estar muito mais perto do que gostaríamos e as "futuras gerações", podem ser mesmo a próxima (a de nossos filhos ou de nossos netos), daí a urgência da questão e a atualidade da necessidade de intensificação da cooperação para se lograr alguns objetivos básicos para a existência humana. 
Na maioria dos cenários estudados pelo IPCC, os aumentos de temperatura da superfície global para o fim do século 21 devem ultrapassar os $1,5^{\circ} \mathrm{C}$ em relação a $1850-1900$, podendo chegar, porém, a $2^{\circ} \mathrm{C}$, É muito provável que mais da metade do acréscimo observado na temperatura média da superfície global de 1951 a 2010 tenha sido causado pelo aumento de gases de efeito estufa, emitido, por atividades humanas. Algumas das principais emissões de $\mathrm{CO} 2$, metano (CH4) e óxido nitroso (N2O) remontam ao início da era industrial (IPCC, 2013).

Quando se aumenta a temperatura média do planeta de forma tão abrupta sérias consequências são geradas, das quais as mais decantadas são o aumento do nível do mar e as possíveis catástrofes climáticas como tempestades e furacões. Mas, os riscos são ainda maiores, pois podem conduzir também (ou melhor, intensificar) a guerras pelos recursos naturais, por conta de fatores multiplicados pelos efeitos do aquecimento global.

O aumento do nível do mar se daria pelo incremento da temperatura do planeta, já que induziria a fusão dos gelos das calotas polares, do gelo marinho assim como dos glaciares. Quando isso acontece, aumenta a quantidade de água que desemboca nos oceanos de todo o planeta, o que leva ao aumento drástico dos seus níveis, o que obviamente coloca em perigo as numerosas cidades situadas em nível do mar.

As ondas de calor também deverão se ver potencializadas e se tornarão mais comuns nos próximos anos, dando lugar a enfermidades específicas, bem como podem desencadear muitos incêndios de grandes proporções. De maneira análoga, os padrões das chuvas também estão se modificando muito e as águas mais quentes dos oceanos alimentam a intensidade das tormentas e provocam um maior número de furacões extremamente devastadores, ocasionando inundações, danos às propriedades e mortes.

No polo oposto ao das inundações, as secas. Com o aquecimento do planeta os períodos de seca aumentam e a quantidade de água doce disponível diminui, dificultando a agricultura eprejudicando a produção de alimentos. Um dos principais efeitos disso é queo alcance dos objetivos de combate à fome do mundo tende a ficar ainda mais distante. Pelo sim, pelo não, o alerta está dado e o discurso de minimização precisa ir para a prática. Tal encaminhamento, entretanto, encontra-se prejudicado pela grande dificuldade, originária da hegemonia das perspectivas de curto prazo na avaliação da atividade econômica, em se inserir os custos ambientais no cálculo dos preços dos produtos. Em tese, essa dificuldade seria decorrente das prescrições ambientais mais exigentes, que prejudicariam a dinâmica do mercado e provavelmente acirrariam, ainda mais, as desigualdades no curto prazo. Países, empresas e consumidores ainda não se habilitam ao primeiro passo como efetivamente deveriam. Enquanto fazem operações cosméticas, preferem esperar para ver. É o autointeresse de curto prazo imperando. E por que isso ocorre? 
No polêmico O Gene Egoísta, o biólogo inglês Richard Dawkins afirma que se desejarmos

\begin{abstract}
uma sociedade na qual os indivíduos cooperem generosa e desinteressadamente para um bem comum, devemos esperar pouca ajuda da natureza biológica. $\mathrm{O}$ adepto da seleção individual admitiria que grupos realmente desaparecem e que o fato de um grupo extinguir-se ou não pode ser influenciado pelo comportamento dos indivíduos naquele grupo. Ele talvez admita que "se ao menos" os indivíduos em grupo tivessem o dom da previsão poderiam perceber que em longo prazo é de seu interesse refrear sua ganância egoísta para impedir a destruição do grupo todo. [...] mas, a extinção de um grupo é um processo lento comparado com a luta rápida da competição individual. Mesmo enquanto o grupo declina vagarosa e inexoravelmente, indivíduos egoístas prosperam às custas dos altruístas (Dawkins, 1979, p.25).
\end{abstract}

Destaque-se que na natureza, os problemas enfrentados normalmente se referem à escassez, que faz com que na luta pela sobrevivência, sejam aflorados os instintos de proteção genéticos. Na sociedade atual, embora muitos vivam o problema da escassez, a questão real envolve ainda mais do que isso, ou seja, a distribuição dos recursos.

O grande empecilho para que a cooperação e o comportamento altruísta sejam disseminados é que a luta rápida da competição individual é o mote de existência do sistema capitalista, tão bem apropriada na leitura dos instintos genéticos do homem e traduzida pela teoria econômica convencional. A competição entre os agentes, mediatizada pelo mercado, na busca por eficiência e recompensa (o mérito) tende a prescindir do longo prazo, no qual as consequências marginais dos atos presentes podem tornar-se irreparáveis.

Após ter recebido muitas críticas pelo seu evolucionismo mecanicista, alguns anos depois da publicação do O Gene Egoísta, no seu livro Desvendando o Arco-Íris (Dawkins, 2000), no capítulo intitulado "O colaborador egoísta", Dawkins sofisticou a sua ideia agregando-lhe a informação de que cada gene tem de ser bom em se reproduzir juntamente com uma comunidade, o genoma, ou pool de genes da espécie. Como só existem genes dentro de genomas, a sobrevivência dos primeiros dependeria da manutenção dos outros. "Sobreviver", no caso, quer dizer disseminar-se, tornar-se o mais frequente numa população. Para isso seriam necessárias estratégias adicionais que permitiriam a manutenção dessa ordem maior.

Mas a luta rápida continua, e o próprio Dawkins já havia conjecturado que,

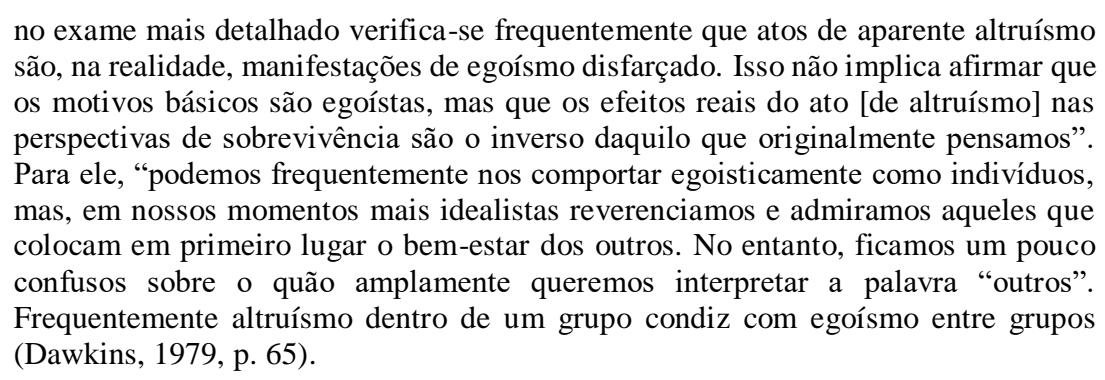

As dificuldades atuais para que as práticas econômicas sejam realmente sustentáveis e deixem o nível da prática cosmética encerram tal tipo de atitudes. O grupo e os "outros" (mesmo 
sem saber quem são) assumem posições delimitadas e o interesse é competir entre si para ver quem fica com a parte mais aquinhoada.

\section{COOPERAÇÃO SOCIAL}

Como escrito anteriormente, uma das principais abordagenspor parte da ciência econômica relativamente ao tema da cooperação (ou de sua dificuldade), pode ser encontrada na Teoria dos Jogos. Depreende-se dessa teoria que o tipo de resultado a ser obtido em uma negociação depende do tipo de jogo envolvido nessa mesma negociação. Esse jogo pode apresentar um caráter cooperativo. Nesse caso, espera-se que ambos os agentes cheguem a um acordo benéfico para as partes. Nocaso do jogo ser não cooperativo (numa lógica exclusiva de curto prazo), no qual a informação é limitada, o resultado esperado é que um agente seja beneficiado e outro prejudicado. Tal resultado, em escala ampliada, tende a gerar dissensões sociais. A colaboração, no caso, só se torna possível se os indivíduos adotarem uma estratégia de cooperação com o objetivo egoísta de obter um melhor resultado para si no longo prazo. Mas a lógica limitada ao curto prazo ainda é a tônica na atualidade, tanta na prática cotidiana das atividades econômicas quanto na teorização dessas práticas pelas correntes teóricas dominantes da ciência econômica.

A cooperação social se realiza entre pessoas, em um processo de comunicação aberto e em um contexto de decisões repetitivas (conforme demonstrado por Axelrod, 1997). Como é que a cooperação pode surgir em um mundo em que cada um segue seu interesse pessoal? A resposta é que a cooperação terá lugar se os jogadores esperarem que os eventos nos quais essa cooperação se revela necessária se repitam no futuro. Do ponto de vista da racionalidade de curto prazo, ela consiste na maximização das satisfações individuais, isto é, fazer o melhor que se pode para si mesmo, naquele evento ou naquele curto intervalo de tempo. No entanto pessoas racionais podem não cooperar com outras, apesar da vantagem evidente que poderiam obter por também favorecer o outro.

E no caso de problemáticas ambientais, tais como a do aquecimento global e da incapacidade de absorção dos resíduos resultantes das atividades econômicas desenvolvidas no planeta como um todo? Qual seria a ameaça que realmente convenceria as pessoas sobre os riscos assumidos e socializados por todos? Trata-se de mais uma manifestação de uma estratégia que no nível micro é o conhecido exemplo da "Tragédia dos Comuns", formulada por Garret Hardin (1967). A solução proposta por Hardin ao problema passava pela redefinição da propriedade de cada bem (ao menos assim entenderam os economistas neoclássicos): a socialização ou a privatização dos recursos, ambos buscando solucionar o problema do conflito de interesses que conduz de maneira gradual à destruição dos recursos e meios de subsistência de seus utilizadores. 
Ao estabelecermos a relação entre o comportamento autointeressado e a teoria do gene egoísta, poderemos ter uma primeira explicação para a competitividade de mercado incentivada, dado que o resultado das transações no mercado representariam um caminho em direção ao ponto ótimo:

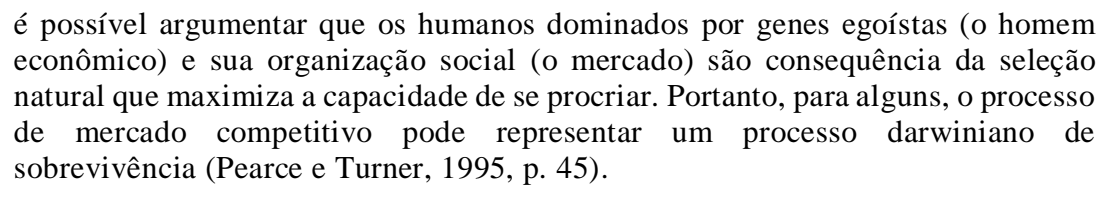

No debate atual sobre a sustentabilidade, o problema é observado na prática. As previsões mais realistas dão conta de uma piora gradual dos fundamentos ambientais do planeta, e elas são francamente subestimadas em razão de uma lógica econômica imediatista e "curtoprazista". Os agentes econômicos esperam que os outros tomem atitudes sustentáveis e que os efeitos dessa prática, dos outros, já beneficiem a todos de uma maneira ampla. Por conta desse tal raciocínio, as negociações em torno de um acordo global para o clima nos últimos anos têm mostrado seguidos fracassos, denotando a indisposição da negociação, o que leva o jogo a não apresentar um resultado definido. Protelação, procrastinação do problema tornam-se estratégias deliberadas paraadiar qualquer decisão ao limite do insustentável, ou, até quando se esgotarem as capacidades de argumentação por meio dos sofismas estratégicos amplamente divulgados.

Sob a ditadura neoliberal do mercado globalizado, muitas das nações desenvolvidas, imersas na busca, de curto prazo, por competitividade econômica, acabam por não investir na adoção das políticas de sustentabilidade. Essa atitude expressa a suposição implícita de que se outras naçõesadotarem tais políticas, elas poderão desfrutar das benesses de um modo de vida menos poluente, sem precisar assumir os custos que potencialmentediminuiriam a sua competividade. Enquanto isso, a cooperação entre as partes passa ao largo.

Foi com essa linha de raciocínio que o presidente norte-americano, Donald Trump, tão logo eleito, retirou os EUA do Acordo de Paris (tão festejado em sua assinatura por 195 países em 2015). "Vamos crescer, não vamos perder empregos", foi seu principal argumento. Se os outros países admitem colocar entraves em termos ambientais para redirecionar as suas atividades econômicas, esse não é o caso dos Estados Unidos na concepção de seu atual mandatário. Uma opção que quase foi seguida pelo recém-eleito presidente Jair Bolsonaro no Brasil.Esse comportamento, no entanto, não se dá apenas na esfera dos países e de suas economias.

Para Bowles (2004) é errôneo entender tal comportamento como simplesmente sinônimo da busca pelo bem-estar próprio. Vários estudos, como os de Kahneman e Tversky (2011), mostraram que o comportamento humano pode ser míope no que tange ao próprio bem-estar do sujeito. Bowles também rejeita a ideia samuelsoniana de "preferência revelada", pelo fato dela pouco explicar as razões para o comportamento do agente econômico (o que o 
conduziu a tal escolha?). Dentro da visão de Bowles, emoções e comportamentos não-ótimos deveriam também fazer parte do estudo do economista, pois são capazes de explicar melhor os comportamentos humanos. Interessante observar que a estrutura dos jogos revela um caráter a-histórico que parece entrar em conflito com a própria ideia de troca disputada, que visava dar mais realismo às relações econômicas dentro do capitalismo. Afinal, se a troca pode ser modelada como um jogo, a pergunta mais importante é: quem faz as regras desse jogo dentro de uma sociedade e época específicas?

Em suma, existe a possibilidade de as regras do jogo serem alteradas à medida em que o jogo é jogado e dependendo das intenções de quem o joga? Entendemos que isso é possível; mas em primeira instância (no curto prazo), na expectativa de que a maioria (os outros) faça a sua parte, alguns deixam de cooperar, mantendo o seu padrão de consumo e de conduta, enquanto os outros realizam seus pequenos sacrifícios, mas numa escala insuficiente para mitigar as transformações.

Os exemplos são fartos. A Teoria dos Jogos explica, por exemplo, porque as colherinhas de açúcar para o café gradualmente desaparecem das áreas comuns de escritórios. Tecnicamente falando, os usuários de colheres tomam decisões considerando que a utilidade deles (seus próprios benefícios) cresce bastante ao pegar uma colher para uso pessoal enquanto a utilidade de todos os demais colegas diminui uma pequena fração per capita (afinal, no começo do raciocínio há ainda um monte de colheres). Mas, à medida que todos tomam a mesma decisão, todas as colheres comuns tendem a sumir do cenário.

Na mesma medida, em um condomínio onde a água do prédio ainda é dividida de forma igual a todos os apartamentos, o morador pode pensar: "se eu gastar um pouco mais não pagarei pelo meu consumo, ou pagarei muito pouco pelo excedente, pois a conta será dividida por todos os 50 condôminos". Raciocínio análogo: "porque vou tomar um banho corrido de 3 minutos, enquanto o vizinho ouve um disco inteiro no chuveiro?”. É por isso que a tendência dos edifícios mais modernos é possuir medidor individual para cobrar o consumo exato de cada unidade. A conscientização da necessidade de economia de água é extremamente difícil e apelos ao consumo sustentável só se concretizam em períodos de grave crise (que podem se tornar constantes no futuro se não houver tal mudança de comportamento). Em São Paulo, a crise hídrica de 2014/2015, por exemplo, fez a companhia de saneamento implantar o racionamento e utilizar o chamado volume morto das suas represas. Passada a crise hídrica, gradativamente as pessoas voltaram a gastar no patamar que se verificava no período anterior. Tarifas, isto é, preços mais altos e um aviso travestido de ameaça convincente resolveram a situação no seu momento mais crítico, mas na volta à normalidade o comportamento perdulário ressurge e a ameaça desaparece. Em algum momento, o risco foi realmente visível e houve a mudança de atitude, o que conduziu 
ao sucesso da iniciativa. E nos casos do aquecimento global e da incapacidade de absorção dos resíduos emitidos pelo planeta como um todo? Qual seria a ameaça que realmente convenceria as pessoas sobre os riscos assumidos e socializados por todos? Assim como na crise da água, o problema só passou a realmente existir quando houve o risco real de as pessoas ficarem efetivamente sem água, o que até então parecia uma ficção.

O problema do aquecimento global é mais uma manifestação da já citada "Tragédia dos Comuns". Em um de seus conhecidos exemplos, Hardin (1967) parte da análise do processo de apropriação das cabeças de gado para pastagem que se deu na Inglaterra no século XIX, caracterizado pelo cercamento dos campos de forma física e jurídica, o que ocasionou um acirramento de interesses entre seus utilizadores. Na história modelo, um grupo de pastores cuidava de seus animais numa terra pública, compartilhada entre todos. Seguindo o cálculo racional individualista, cada pastor pensava em adicionar um animal ao seu rebanho: um animal a mais lhe acrescentaria um lucro adicional, e no geral a pastagem diminuiria de forma apenas marginal, então parecia perfeitamente lógico aos pastores colocarem um animal extra. A tragédia do pasto comum ocorre quando todos os outros pastores pensam da mesma maneira ("se eu não ficar esperto, o outro passa na frente, e eu vou ficar sem nada"). Quando todos resolvem adicionar um animal (por não confiar no outro), a terra se torna superpovoada e em breve não haverá mais nenhum espaço para pastagem, ou seja, só sobrará um pasto degradado.

A solução proposta por Hardin ao problema passa pela redefinição da propriedade. Numa análise liberal, se o pasto tivesse um dono estabelecido ele deixaria fazer com que ficasse deteriorado, esgotando assim a sua fonte de renda? Teria interesse em matar a sua galinha dos ovos de ouro? Não, não parece sensato. A não ser que a oferta seja muito boa e os ganhos muito promissores. Este é um exemplo de uma vertente teórica do liberalismo político ambiental (Sales, 2006, p.58).

\section{BENS E RECURSOS COMUNS}

Buscando apresentar outra perspectiva à privatização, a cientista política Elinor Ostrom analisa a "Tragédia" apontando o erro de Hardin, ao confundir recursos de livre acesso com recursos comuns. Para Ostrom, Garner e Walker (1994), aquilo que Hardin define como commons são os recursos que não estão sob uma jurisdição comum e não podem ser considerados um bem comum a todos os agentes envolvidos. Sua resposta à tragédia apresentada reside no conceito de propriedade comum e cooperação entre os agentes que dependem dos recursos, advogando um sistema de acordos que dependa menos do Estado, mas de forma a aproximar o diálogo entre os interessados, aumentando a confiança entre as partes. A cooperação entre os agentes se daria de tal forma que os mesmos seriam responsáveis pela formulação e aplicação de políticas que 
ocasionassem o benefício de todas as partes envolvidas, respeitando os limites impostos pela natureza. Ostrom, da Universidade de Indiana, foi a primeira mulher a receber o Prêmio Nobel de Economia, em 2009, juntamente com Oliver E. Williamson, quando a Real Academia de Ciências da Suécia destacou a sua obra pela análise da governança econômica, principalmente no que toca aos recursos compartilhados.

Refazendo a trajetória do conceito. A teoria econômica clássica classificou os bens de forma binária em públicos e privados e não reconheceu o conceito de bens comuns como uma categoria específica. Em sua proposição, Elinor Ostrom apresentou um enfoque dos bens comuns que permite visualizar a sua especificidade conceitual por meio de uma metodologia que examina as formas em que os bens econômicos ocorrem diretamente na realidade, o que contrasta com a classificação padrão que deduz as suas categorias a partir de uma modelagem abstrata. A obra de Ostrom se insere no marco conceitual da Nova Economia Institucional, que a partir da análise microeconômica desloca o seu foco para aspectos habitualmente negligenciados pela economia convencional, tais como os custos de transação, os estudos das regras do jogo, os mecanismos de controle e manutenção dos acordos sociais. A partir desse enfoque, Ostrom tentou conciliar sob uma mesma perspectiva econômica os conceitos de eficiência e sustentabilidade, destacando o papel das instituições, a necessidade de atender a variável temporal, os incentivos à mudança institucional e os custos de transação.

A tese fundamental de sua obra diz mais ou menos o seguinte: não existe ninguém melhor para gerir de forma sustentável um "recurso de uso comum" do que os próprios envolvidos (Ostrom, 1995, p.40). Mas para isso algumas condições precisam ser fornecidas: disponibilidade de meios e incentivos para exercer os seus direitos, existência de mecanismos de comunicação necessários para sua gestão e um critério de justiça baseada na divisão equitativa de custos e benefícios.

Para melhor compreender a importância da abordagem de Ostrom é um bom expediente resgatar os aportes da teoria dos bens públicos desenvolvida por Paul Samuelson (1954), que os define como aqueles bens que não é viável nem desejável racionar o seu uso e cujo uso ou consumo individual não impede o consumo por parte de outros. Musgrave (1959) complementou essa classificação introduzindo a variável de excluibilidade e também o conceito de bens meritórios. A excluibilidade é importante porque descreve a possibilidade de apartar do uso ou consumo de um bem aquele que não paga por ele. Um bem é não-excluível quando tecnicamente, ou por razões de custo, não é possível impedir que quem não contribui acabe acessando o recurso. Essa classificação não indica necessariamente a propriedade privada ou estatal, já que ambos podem ser providos tanto pelo setor público quanto pelo privado. Os bens meritórios são aqueles que, embora possam ser explorados pelo setor privado, podem e devem ser produzidos pelo setor 
público para evitar que a população de baixa renda seja excluída de seu consumo, como é o caso da saúde e da educação.

James Buchanan, outro Prêmio Nobel de Economia, deu também a sua contribuição ao debate estabelecido por Samuelson com a introdução da ideia de bens puros e impuros, que ia apenas um pouco além da simples descrição do regime de propriedade jurídica até então vigente. A intenção de Buchanan foi sanar o que denominou "a incrível distância estabelecida por Samuelson entre o bem puramente privado e o bem puramente público" (1964, p.14). A partir de Buchanan se começou a falar de bens públicos impuros como uma categoria intermediária entre os bens privados e os bens públicos puros. Mas esse esquema identificou apenas um tipo de bem impuro: os chamados "bens de clube". Os bens comuns e os bens de clube se assemelham na medida que podem ser utilizadas ou consumidos de modo coletivo. A diferença é que os bens de clube incluem uma cota ou pedágio de acesso que podem excluir parte de seus consumidores de acordo com critérios de mercado. Por isso, podem ser chamados também de "bens artificialmente escassos" e se definem como aqueles que satisfazem as necessidades dos usuários de forma gratuita e livre no momento do uso, mas implicando em custos compartilhados de entrada; a imagem é a de um sócio de um clube que pode usufruir de todas as instalações disponíveis, mas para isso precisa adquirir antes um título de sócio.

O aporte de Buchanan conseguiu sofisticar o esquema binário de Samuelson, mas ao introduzir o conceito de bens de clube, conseguiu apenas por em tela os bens excluíveis, mas não rivais; não conseguiu focar o caso contrário: os bens rivais, mas não excluíveis. No seu ensaio, Paul Samuelson (1954) dividia os bens em dois tipos: i) bens privados puros são tanto excluíveis (o individuo A pode ser excluído do consumo de bens privados a menos que pague) e rivais (o que o individuo A consome, ninguém mais pode consumir); ii) bens públicos não excluíveis (não se pode separar os que pagaram e os que não pagaram) e não-rivais (o consumo de um indivíduo não limita o consumo de outro). Ostrom via nessa leitura de Samuelson, Musgrave e Buchanan uma visão maniqueísta de análise que simplesmente opunha o estatal e o privado e reduzia o papel do cidadão ao de mero consumidor ou votante (Ostrom, 2009, p.410).

Para superar tal dicotomia entre o público e o privado, Ostrom desenvolveu um enfoque que dá relevância ao que chama de bens comuns, mediante o exame da natureza e das formas em que se manifestam na realidade. O trabalho de Ostrom se caracteriza assim por analisar de forma sistemática uma ampla gama de mecanismos institucionais orientados para administrar e gerir os recursos de uso comum.

No tratamento clássico dos bens públicos, tanto Samuelson quanto Musgrave colocavam ênfase no aspecto da exclusão. Os bens que podiam ter seu consumo excluído por outros indivíduos, além daquele pagante, eram considerados bens privados. Quando os economistas se referiam a esses 
temas, a preocupação central então era a impossibilidade da exclusão. Mais tarde essa discussão passou a se centrar numa classificação baseada no alto custo da exclusão. A questão da rivalidade veio a ganhar maior importância depois. Esta se refere a aqueles bens que somente podem ser consumidos por um número limitado de pessoas ao mesmo tempo; a utilização por parte de uma pessoa ou ator econômico limita o uso dos demais, porque todos os bens teriam um número ótimo de usuários que poderiam compartilhá-los. Ostrom propôs um esquema que vincula a rivalidade como um determinante de igual importância que a excluibilidade na natureza de um bem, o que levou a uma classificação bidimensional baseada simultaneamente em dois eixos, obtendo um quadro com quatros tipos de bens que permite visualizar especificamente os bens comuns, o que não era possível nos esquemas de Samuelson ou de Buchanan.

A novidade da abordagem de Ostrom está no fato de que ela evidencia que existe uma forma coletiva de uso e exploração sustentável dos campos de pastagem (e dos bens comuns em geral) que não está fadada à tragédia dos comuns. Proteger o pasto de Hardin reconhecendo-o como bem rival, não implica necessariamente em recorrer aos direitos de propriedade individual ou a outros mecanismos de exclusão que proporciona o mercado. Ostrom mostra que as formas de exploração comunal podem proporcionar mecanismos de autogoverno que garantem equidade no acesso, um controle radicalmente democrático, uma vez que podem proporcionar proteção e vitalidade ao recurso compartilhado. Ante a possibilidade de sobreexploração, a opção de Ostrom é "incrementar a capacidade dos participantes para mudar as regras coercitivas do jogo a fim de alcançar resultados distintos aos das anunciadas tragédias". Nessa busca, é importante identificar práticas concretas que apontem os princípios que permitiram a muitas comunidades, em todo o mundo, a alcançar um alto nível de autonomia na gestão eficiente dos bens comuns através dos tempos. Sim, eles existem. E a confiança nos demais agentes é um ingrediente fundamental para que os acordos sejam possíveis.

A ausência de propriedade individual não implica livre acesso nem falta de regulação, já que os bens comuns podem ser administrados de forma efetiva se contarem com um grupo de interessados que atuam juntos para garantir a rentabilidade no longo prazo desses bens. Ostrom mostra como diversas sociedades desenvolveram mecanismos institucionais, formais ou informais, legais ou arraigados em costumes que conseguem gerir de forma eficiente os bens comuns e evitam o seu colapso. E a chave explicativa se baseia na ausência da exclusão, o que faz ao introduzir o conceito de "recurso de uso comum" (common pool resources - CPR), um sistema de recursos naturais ou criados pelo homem, suficientemente grande para tornar custoso (embora não impossível) excluir potenciais beneficiários (Ostrom, 2011, p.77).

O termo "grande" está relacionado ao marco da escala no qual está situado o recurso. Um bem comum pode ser pequeno e servir a um grupo reduzido ou pode ter escala comunitária ou 
mesmo se estender ao nível internacional, podendo também ser muito bem delimitado ou mesmo não ter limites claros (Hesse e Ostrom, 2006, p.4-5). Complementarmente, introduz também a diferença entre "sistemas de recursos" e o fluxo de "unidades de recursos" produzidos pelo sistema, enfatizando a sua interdependência (Ostrom, 2011, p.77). Essas categorias estabelecem a diferença entre uma área de pesca (o sistema de recursos) e as toneladas de pescado capturadas (unidades de recurso) ou entre um canal de água (sistemas de recursos) e os metros cúbicos de água por segundo que se utilizam para a irrigação (unidades de recurso).

Dessa forma, ficam muito melhor diferenciados os proprietários do sistema de recursos dos apropriadores das unidades de recurso. Por exemplo, os irrigadores que extraem unidades de recursos de um canal fluvial ou os pastores que utilizam um trecho de pasto podem ser legítimos apropriadores de unidades de recurso sem serem proprietários do sistema. As unidades de recurso podem ser rivais (a água utilizada por um irrigador não pode ser usada por outro), mas o sistema de recursos pode ser utilizado de forma conjunta por muitos apropriadores. No caso dos recursos renováveis, essa distinção se estabelece também sob as categorias "estoque", equivalente a sistema de recursos, e "fluxo", a unidades de recursos.

A maioria dos recursos de estoque comum é suficientemente grande para que vários atores possam usar simultaneamente o sistema de recursos e tenham os esforços para excluir potenciais beneficiários tenham custos elevados. Exemplos de recursos de estoque comum incluem tanto sistemas naturais como sistemas feitos pelo homem, que abarcam aquíferos subterrâneos, sistemas de irrigação, bosques, pastos, servidores de computador, fundos governamentais e corporativos e a internet. Exemplos de unidades de recurso que se derivam de tais recursos incluem água, madeira, pastos, unidades de processamento, bits de informação e assinaturas (Ostrom, 2002, p.2). Além disso, Ostrom distingue entre os produtores de um CPR dos seus provedores. Por exemplo, um governo atuando como construtor de uma obra pública de irrigação pode atuar como provedor para entregar em usufruto esse canal aos irrigadores que atuarão como produtores do mesmo, encarregando-se de sua administração ao mesmo tempo em que extraem unidades de recurso. Para tanto, é necessário diferenciar claramente entre o "sistema de recursos" e o regime jurídico de direitos de propriedade no qual está situado esse sistema, o que é necessário para que os sistemas de recursos compartilhados constituam um bem econômico reconhecível independentemente do sistema de direitos de propriedade no qual se encontram. Schlager e Ostrom distinguiram cinco formas de exercício do direito de propriedade no âmbito dos bens comuns materiais: acesso, extração, manejo, exclusão e alienação (Schlager e Ostrom, 1992). Essa diversidade daria conta das múltiplas possibilidades que podem surgir na gestão dos bens comuns, o que exige além da auto-organização, uma forte capacidade de ação coletiva e autogestão, assim como um alto grau de capital social por parte dos interessados. 
Além dos casos positivos de administração do bem comum, Ostrom também se detém nas experiências fracassadas (ou não tão bem sucedidas). A partir delas, definiu alguns princípios institucionais que caracterizariam a sustentabilidade da administração dos sistemas de recursos comuns (Ostrom, 2011, p. 165-185) e que tendem a melhorar os níveis de cooperação, enquanto a sua ausência tende a deprimi-la. De maneira geral, as aportações de Ostrom e sua escola superam as análises convencionais que se movem sob categorias binárias que transitam entre o próprio e o alheio, o estatal e o privado, o de todos e o de ninguém. E demonstra que a compreensão dos bens comuns está em estreita relação com os conceitos que se manejam a partir do Estado, mercado e das relações de poder e posse nas quais está relacionado.

Para Ostrom, a inconsistência dos direitos de propriedade poderia ser revista, a partir da própria conscientização social na qual os exploradores buscariam novos moldes de exploração dos recursos, que passariam a igualitários e coletivos, regulados por convenções estabelecidas entre os exploradores obedecendo, assim, suas necessidades e costumes. Em vez dos commons, seriam os recursos de uso comum, que apresentaria um viés de longo prazo para a resolução dos problemas de propriedade, diferenciando-se da solução de curto prazo de Hardin (Ostrom, 1990).

Em outra linha de análise, mas corroborando Ostrom, o geógrafo espanhol Horacio Capel (2003) procurou identificar os exemplos de sucesso de gestão de recursos baseados na cooperação entre os agentes ao longo da história. Para o geógrafo espanhol, desde o início do século XX tem ocorrido um acirramento do processo de apropriação do espaço e dos recursos terrestres. Cada vez mais a superfície do planeta Terra tem sido apropriada e tem deixado de ser um bem comum. Ainda seguindo Capel, e na mesma linha de Ostrom, existem possibilidades para formas de gestão comunitária espacial dos recursos que facilite a prosperidade coletiva mais que a individual. "Diante de tudo isso, o problema dos bens comuns se apresenta de forma clara, e se converte em uma luta de caráter político, ou seja, num problema de ecologia política" (Capel, 2003).

Na situação atual de domínio da propriedade privada, que não tem sido capaz de resolver os problemas como aventado por Hardin, talvez convenha o ressurgimento da luta em defesa dos bens comuns em prol do bem da humanidade. Se os princípios éticos combinados não conseguem guiar a busca da ação coletiva, um caminho é a discussão de possíveis regras coletivas de cumprimento obrigatório, e desenvolver uma ação pedagógica muito clara que convença os cidadãos de onde estão seus reais interesses coletivos e, por extensão, individuais, já que estamos falando de acontecimentos em escala planetária. Tanto a "Tragédia" quanto o "Dilema do prisioneiro" ilustram a mesma questão da necessidade de cooperação para obtenção dos melhores resultados. Por se tratar de uma negociação, desde a escala global às comunidades, todos precisam buscar entendimentos sobre o tema, propondo soluções que não penalizem alguns poucos e que, ao mesmo tempo, busquem privilegiar e incluir mais pessoas. 
Vivemos na atualidade um paradoxo: os indivíduos não se organizam para defender seus interesses pessoais, ou tem dificuldade para isso, exatamente devido ao fato de que seus interesses pessoais lhes impedem de participar voluntariamente nas atividades de tal organização comum. Frente aos grandes desafios globais hodiernos, apenas tal organização e determinação dos reais interesses comuns é que fariam a diferença para a conquista de resultados realmente significativos. O problema é que o ensinamento planejado revelou-se uma estratégia muito mais poderosa e mostra que os outros grupos, menores, mas mais poderosos, mas que possuem interesses antagônicos, se organizam melhor, sob a mesma lógica. A história da humanidade se constitui numa miríade de exemplos em que grupos organizados, ainda que pequenos, tomam conta de uma situação mais ampla. O ponto é que para os cidadãos poderem defender seus interesses é necessário saber se organizar.

Além da perspectiva neoclássica, é importante também uma ampliação da compreensão das forças que regem ou podem reger o mercado. A sociologia econômica (Swedberg, 2004), nesse sentido, é um aliado interessante para melhor compreender as mazelas contemporâneas, ao partir da constatação de que os padrões de relacionamento e as instituições sociais e políticas jogam um papel importante nesse cenário.

Segundo a perspectiva sociológica - amplamente contrária à perspectiva econômica neoclássica -, os mercados competitivos não estão formados por atores econômicos "atomizados" sem contato entre si. Sua literatura afirma que a capacidade competitiva dos mercados está associada a instituições, regras e normas que são resultado de ações coletivas e de colaboração entre os atores econômicos. "Muitas perguntas sobre as condições que facilitam ou obstaculizam as transações econômicas e as ações coletivas para a geração de bens públicos ainda não foram respondidas" (Wanderley, 2008). Também não são devidamente focadas as questões sobre os tipos de redes sociais (mercantis e não mercantis) que permitem o surgimento de um padrão de transações econômicas que combine dinamicamente competição e colaboração.

Várias explicações podem ser sugeridas para a formação de ações coletivas entendidas como a associação de sujeitos econômicos que procuram garantir benefícios coletivos por meio de um esforço comum. Essas análises também oferecem explicações sobre as condições para a formação de cooperação econômica em termos de instituições e de relações sociais que facilitam as transações e resolvem disputas na esfera econômica.

Além das políticas de comando e controle e das reformas de cunho fiscal, é interessante também promover formas de organização que superem as ações baseadas no autointeresse de curto prazo. Ostrom sintetizou suas ideias em Governing the Commons na qual afirma que realmente existem muitas soluções que lidam com muitos problemas diferentes, mas em vez de presumir que existem soluções institucionais ótimas que podem ser projetadas com facilidade e 
impostas com baixos custos por autoridades vindas de fora, a sua real efetivação é um empreendimento muito difícil e que envolve a resolução de muitos conflitos (Ostrom, 2011). Em vez de basear a política na presunção de que os indivíduos são indefesos, Ostrom sugere aprender com a experiência desses indivíduos na expressão de acordos.

Ostrom observa que os problemas de sobreutilização dos recursos geram a necessidade de mudar a maneira como os membros de uma sociedade se comportam; e isso não é fácil, por vários motivos. Para começar, neste tipo de situação, o comportamento de cada um está essencialmente ligado ao dos outros, e é muito difícil prever como os outros se comportarão, ou como eles responderão à introdução de uma nova norma. Após muitos anos de glorificação da atitude egoísta, é preciso restituir a confiança entre os pares.

De forma mais localizada, membros de uma comunidade com um recurso comum têm certas vantagens. Assim, eles têm conhecimento da terra e das pessoas que as ajudam. É um conhecimento "de tempo e lugar", na expressão de Ostrom. Este conhecimento de base empírica, em combinação com a razão, leva à elaboração de padrões que são testados com a experiência e são posteriormente refinados, em um processo de tentativa e erro, até que se torne um conjunto de instituições, que carrega em si uma inteligência sutil na resolução de conflitos, o que leva a comunidade a explorar de forma equilibrada o recurso em questão.

Com essa linha de argumentação, Ostrom chega a "uma teoria da ação coletiva autoorganizada" na qual, "ao invés de supor que alguns indivíduos são incompetentes, maus ou irracionais enquanto outros são oniscientes", presume que os indivíduos têm "capacidades limitadas muito similares para pensar e buscar soluções em ambientes ou entornos complexos".

Quando olhamos para os casos que Ostrom coloca como paradigmas do gerenciamento bemsucedido de bens comunais, verificamos que não nos mostra uma situação de parcelamento de terra, com uma definição perfeita dos direitos de cada um, mas alguns acordos que, no fundo, se assemelham a uma privatização do recurso. O seu caso modelo preferido é o da cidade mediterrânea turca de Alanya, que

\footnotetext{
oferece um exemplo de um acordo comunal de boa governança em que as regras foram concebidas e modificadas pelos próprios participantes (...), embora não seja um exemplo de livro de propriedade privada, os direitos de exploração dos locais de pesca e os deveres de cada em relação a esses lugares estão bem definidos (Ostrom, 2011, p.65).
}

Nos exemplos de gestão de recursos comuns mal-sucedidos, um dos problemas mais comuns é a falta de comunicação entre os participantes, mas um elemento que é repetido em vários dos exemplos que coloca é o da importante ação do Estado, sobre o qual é geralmente crítica. "Sem informações válidas e confiáveis, uma agência central pode cometer numerosos erros", e é preciso haver um mecanismo como o "mercado competitivo", para exercer "pressão sobre o governo para criar instituições eficientes". Apesar do seu enfoque comunal, Ostrom 
argumenta que existem maneiras de gerenciar recursos que não são propriedade do Estado ou do setor privado, mas que se enquadram na esfera privada e que se beneficiam de um ambiente com mercados competitivos. O mais importante é ter a capacidade de articulação e gestão para fomentar os acordos e que estes sejam cumpridos.

Do nível microeconômico das organizações coletivas à escala das preocupações planetárias: os recursos naturais globais ou os bens comuns globais não são "bens comuns" no sentido estrito da palavra e como é projetado na visão da Ostrom, mas muitos deles ainda pertencem teoricamente às categorias de bens livres e até mesmo res nullius, cujo acesso é livre e cuja regulamentação escassa ou nula permite seu uso e/ou exploração individual ilimitada, até sua apropriação total, com a consequente deterioração do bem. Isso é, por exemplo, o que ocorre na área de alto mar e na atmosfera (no fenômeno das mudanças climáticas), que apresenta a situação dramática na qual o acesso livre e geral está disponível para qualquer usuário, e cada uso que é feito do bem tira da sua capacidade de servir ou ser usado por outros. A discussão sobre a questão do aquecimento global é basicamente isso. Quanto cada um pode emitir de poluentes em um nível sustentável? Ou, qual seria esse nível sustentável? De qualquer maneira, o que já sabemos é que esse ponto já foi superado, daí a urgência de um acordo global.

\section{ALGUMAS CONSIDERAÇÕES FINAIS}

Sob o nome de Laudato Si (Louvado Seja), com subtítulo Sobre o Cuidado da Casa Comum, o Papa Francisco emitiu em 2015 a segunda encíclica do seu pontificado centrada na urgência de responder, com o que chamou de "ecologia integral", os abusos sofridos pelo planeta (Papa Francisco, 2015). A encíclica é na verdade um manifesto para tomarmos consciência de como habitamos a nossa própria casa: "se os homens, povos, os empresários e nações seguem empenhados em viver nela como se fosse um apartamento compartilhado onde pouco importa o espaço comum e só se preocupam com o quarto que cada um ocupa, ou se, cada um tomará um papel ativo para tornar a casa um lar para a grande família da humanidade". No resumo da encíclica, é preciso intensificar a cooperação entre os homens para cuidar da casa comum. Desenvolver meios para isso, ampliar a cooperação entre os homens, fazendo-os pensar de forma coletiva, muito além do seu autointeresse de curto prazo é um desafio contemporâneo mais do que urgente.

O modelo institucional dos recursos comuns de Ostrom pode servir de base para o tratamento dos bens comuns globais, uma vez que enfrentam os mesmos problemas verificados na esfera microeconômica, com a diferença de levá-lo um nível macroeconômico ou universal. Mas seu papel como modelo ainda é insuficiente ou limitado, dada a extensão dos recursos e o número de atores que usam, participam ou decidem, juntamente com seu alto grau de heterogeneidade ou desigualdade 
econômica, política, geográfica, social, cultural. Isto tudo sem mencionar os altos custos de autogestão, supervisão e controle recíproco, que, como um todo, são fatores que afetam negativamente o nível de cooperação, um requisito indispensável para qualquer regime de bens comuns. Acima de tudo, o alto grau de heterogeneidade ou desigualdade com a consequente assimetria na capacidade ou poder econômico, político, científico, tecnológico e militar dos Estados espalhados ao redor do mundo é o resultado do confronto de posições opostas, levando-os a escolher indiferentemente entre uma ou outra alternativa de tratamento do tema, guiados por sua posição e interesse individual.

Assim como os pastores que querem colocar um animal a mais no posto para que não perdesse espaço para a concorrência, existe uma grande desconfiança também entre os Estados. Não existe a confiança necessária para a cooperação neste nível, porque os Estados estão em uma corrida competitiva que segue as leis do mercado globalizado e que vai na direção oposta à ideia de bens comuns. Estamos, pelo contrário, caminhando a passos céleres para a "tragédia global dos comuns". Isso é preciso ficar claro para todos, do nível individual ao comunitário, da esfera das empresas até o nível dos países em bloco.

\section{REFERÊNCIA BIBLIOGRAFICA}

AXELROD, Robert (1997). The complexity of cooperation: agent-based models of competition and collaboration. New Jersey, Princeton University Press, 1997.

BECK, U. (1995) Ecological Enlightment.Essays on the Politics of the Risk Society.New Jersey: Humanities Press, 1995.

BIANCHI, Ana M. (1988). A Pré-História da Economia, de Maquiavel a Adam Smith. São Paulo, Editora Hucitec, 1988.

BIANCHI, A. M. \& SANTOS, A.T.A. (2005). Adam Smith: filósofo e economista.Cadernos IHU Idéias.Ano 3, n. 35.

BOWLES, S. (2004) Microeconomics: behavior, institutions and evolution.Princeton University Press, Oxfordshire.

BUCHANAN, James (1965) "An Economic Theory of Clubs".En Public Goods \& Market Failures.TylerCowen.New Jersey.

CAPEL, H. (2003)El drama de losbienescomunes. La necesidad de un programa de investigación. Bblio3W, Revista Bibliográfica de Geografía y CienciasSociales, Universidad de Barcelona, Vol. VIII, $\mathrm{n}^{\circ}$ 458, 25 de agosto de 2003. <http://www.ub.es/geocrit/b3w-458.htm>.

CERQUEIRA, H.EA. (2006) Adam Smith e seu contexto: O iluminismo escocês. Economia e Sociedade, Campinas, v. 15, n. 1 (26), p. 1-28, jan./jun. 2006

DAWKINS, R. (1976). O Gene Egoísta. Rio de Janeiro, Rocco, 1976

DAWKINS, R. (2000). O rio que saía do Éden. Rio de Janeiro, Rocco, 2000

FRANCISCO, Papa (2015). “Carta Encíclica LaudatoSi”.São Paulo: EditoraPaulinas, 2015.

KAHNEMAN, D. (2003) "Maps of Bounded Rationality: Psychology for Behavioral Economics", American Economic Review, Vol. 93, No. 5 (Dec., 2003), pp. 1449-1475

KANT, Immanuel [1784]. Resposta à pergunta: que é 'esclarecimento'? Textosseletos.Petrópolis: Vozes, 1984.

HARDIN, G (1968) The Tragedy of Commons". Science, v. 162, 1968, pp. 1243-1248. 
IPCC (2013).Climate Change 2013: The Physical Science Basis. Contribution of Working Group I to the Fifth Assessment Report of the IntergovernmentalPanel on Climate Change [Stocker, T.F., D. Qin, G.-K. Plattner, M. Tignor, S.K. Allen, J. Boschung, A. Nauels, Y. Xia, V. Bex and P.M. Midgley (eds.)].Cambridge University Press, Cambridge, United Kingdom and New York, NY, USA, 1535 pp, doi:10.1017/CBO9781107415324.

OSTROM, Elinor, GARDNER, Roy \& WALKER, James. 1994. Institutional Analysis and CommonPool Resources in Rules, games, and common-pool resources. The University of Michigan Press.

OSTROM, Elinor. 1990. Governing the Commons: The Evolution of Institutions for Collective Active. New York: Cambridge University Press.

OLSON, Mancur (1965). The logic of collective action: public goods and the theory of groups. Cambridge e Londres: Harvard University Press, 1995.

PEARCE, D. \& TURNER, R. (1995).Economics of Natural Resources and the Environment. New York, Harvester Wheatsheaf, 1995

PIKETTY, Thomas (2014). O capital no século XXI / Thomas Piketty ; tradução de Monica Baumgarten de Bolle. Rio de Janeiro : Intrínseca, 2014.

SALLES, P. B. Filiações Teóricas do Ambientalismo Liberal, Libertário e Socialista. Florianópolis, v.5, n.3, p. 57-67, Jul. 2006

SAMUELSON, Paul A. (1954) "The Pure Theory of Public Expenditure". The Review of Economics and Statistics, Vol. 36, No.4. (Nov. 1954), pp. 387-389. [en línea][consulta: 21 de janeiro 2016]

SWEDBERG, P.(2004) Sociologia econômica: hoje e amanhã. Tempo Social [online]. 2004, vol.16, n.2, pp.7-34. ISSN 0103-2070. http://dx.doi.org/10.1590/S0103-20702004000200001.

WCED (1987) - Our common Future. Oxford, Oxford University Press, 1987. 